ARTICLE

\title{
Storage Mycoflora in Sesame Seed Production in Benue State, Nigeria
}

\section{Elaigwu ${ }^{1 *}$ H.O.A. Oluma ${ }^{2}$ A. Onekutu ${ }^{3}$}

1. Department of Integrated Science, College of Education, Oju, Benue State, Nigeria

2. Department of Botany, Federal University of Agriculture Makurdi, Benue state, Nigeria

3. Department of Zoology, Federal University of Agriculture Makurdi, Benue state, Nigeria

\section{ARTICLE INFO}

Article history

Received: 26 July 2021

Accepted: 16 August 2021

Published Online: 7 September 2021

\section{Keywords:}

Storage fungi

Mycoflora

Storage sesame

Benue state

\begin{abstract}
Sesame (Sesamum indicum) is usually contaminated with many fungi where some of them are mycotoxigenic causing economic and health problems. This study investigated the percentage composition of fungi contamination of sesame seeds in Benue state Nigeria. Using direct plating technique; the study revealed twelve species of fungi contamination in sesame seed obtained in Benue State. The percentage occurrence of fungal isolates shows that Aspergillus flavus and A. niger were found in all the locations and their occurrence was significantly different $(\mathrm{P} \leq 0.05)$. The percentage contamination of Sesame samples collected from Otukpo LGA has the highest fungal $(23.35 \%)$ contamination and was significantly higher $(\mathrm{P} \leq 0.05)$ from samples of other places whereas Sesame contamination from Gboko was the least with total percentage of (12.05\%). In conclusion, considering the benefits of sesame, it is recommended that several treatments should be applied to reduce the levels of contamination in sesame seeds before consumption utilization such as environmental conditions leading to fungal proliferation (a high temperature, humidity, poor soil fertility, drought and insect damage). Also poor harvesting practices, unsuitable storage conditions, improper transportation, marketing and processing should be discouraged.
\end{abstract}

\section{Introduction}

Sesame seeds (Sesamum indicum L.), otherwise known as beniseed, grouped under the family pedaliaceae is one of the oldest and most traditional oilseed crops known to mankind ${ }^{[1]}$. It is called 'Queen of oil seeds' due to its high quality polyunsaturated stable fatty acid, which restrains oxidative rancidity ${ }^{[2-4]}$. Sesame production in Nigeria probably began in the Middle Belt (North -Central) region of the country and later spread out between latitudes $60^{\circ} \mathrm{N}$ and $100^{\circ}$ N. Sesame is commonly grown by small holder farmers in Nigeria. The major producing areas in order of priority are Nasarawa, Jigawa and Benue States ${ }^{[5]}$.

Sesame (Beniseed) is one of the major cash crops that are popularly cultivated in Benue State. It was in this regards that OLAM Nigeria Limited distributed Sesame seedlings to 7,000 farmers in Benue and Nasarawa States to improve productivity of the cash crop in $2007^{[6]}$. The prominent sesame producing local government areas of the state are: Makurdi, Gwer-West, Gwer-East, Logo, Katsina-

*Corresponding Author:

M. Elaigwu,

Department of Integrated Science, College of Education, Oju, Benue State, Nigeria;

Email: elaigwumatthew1986@gmail.com 
Ala, Ukum, Agatu, Oju, Obi, Gboko, Ogbadibo, Ohimini, Guma and konshisha, Vandeikya and Otukpo ${ }^{[7]}$. There are three major varieties of sesame cultivated in Benue state: Yandev 55 characterized by smaller seeds and brighter in colour, E7 is with dull colour medium seeds and medium yield and E8 is having bigger seeds, high yielding and more oil ${ }^{[7]}$. Sesame production, and post-harvest handling business, producers, mainly smallholder farmers in Benue state are facing strong constraints and challenges to achieve significant increases in their incomes. Among many constraints is the risk of contamination during storage by mycotoxins especially the unbiquitous and hepatotoxic aflatoxins which are produced when seeds are kept under conditions that favour the development of these fungi ${ }^{[8]}$. The most vital mycotoxins are produced by fungi such as: Fusarium spp, Aspergillus spp, Penicillum spp, Alternaria spp, Emericella spp. These organisms thrive in moist and environments with moderate rainfall. They are regularly found in improperly stored staple commodities such as cassava, chili peppers, corn, cotton seed, millet, peanuts, rice, sesame seeds, sorghum, sunflower seeds, tree nuts, wheat, and a variety of species ${ }^{[9]}$. However, there is dearth of information on fungi contamination with Sesame in Benue state. The objective of this study is to evaluate storage mycoflora contamination in sesame sold in Benue state North central Nigeria.

\section{Materials and Methods}

Benue state is located in the Southern Guinea Savanna which is a transition belt between the grassland savanna in the North and the rainforest in the South. Benue State, Nigeria is designated with (latitude $6^{\circ} 21^{\prime}-8^{\circ} 10^{\prime} \mathrm{N}$ and longitude $7^{\circ} 44^{\prime} \mathrm{E}-9^{\circ} 55^{\prime} \mathrm{E}$ ).

\section{Sampling collection}

The State has three agricultural zones namely: North which comprises (Buruku, Guma, Gboko, Tarka, Makurdi, Gwer-West and Gwer) Local government Areas, East (Konshisha, Vandeikya, Kwande, Ushongo, Katsina-Ala, Ukum and Logo), and South (Apa, Ado, Agatu, Otukpo, Ohimimi, Okpokwu, Ogbadibo, Obi and Oju). For the purpose of this study, two (2) zones were purposively selected; North and South which are known as the belt of sesame production in the State ${ }^{[7]}$. Of these zones, a total of six LGAs including Guma, Gboko and Makurdi (Benue North) and Otukpo, Obi and Ogbadibo (Benue South) was included in the survey. Four samples were collected each from four different markets within each of the six surveyed LGA resulting in a total of 96 samples. Markets from selected local government areas were identified through local government departments' of agriculture and traditional authorities.

\section{Determination of Representative Sample Size (DRSS)}

Research work in this area of study is scanty, as such this research work will served as basis for the estimation of the representative sample size and it was calculated using the formula below:

$\mathrm{S}=\frac{x^{2} P Q}{l^{2}}$

$\mathrm{S}=$ Number of markets/ Centers

$x=$ the $\mathrm{x}$ score for a given confidence interval

$\mathrm{P}=$ Estimated prevalence

$\mathrm{Q}=1-\mathrm{p}$

$l=$ allowable error of estimation

In this research the desired confidence interval was $95 \%$ with an allowable error of estimation 0.05 the estimated prevalence that was considered as $47 \%$ according to Ezekiel and Sombie ${ }^{[10]}$.

\section{Isolation of Fungi by direct plating method}

Sabouroud Dextrose Agar (SDA) was used throughout the study. The method described by Jha ${ }^{[1]}$ Agar plate method was used for the isolation of fungi.

\section{Fungal Identification}

The Sub cultured fungi were primarily identified using cultural and morphological (colony colour, surface texture) features and microscopic characteristics (Nature of spore, conidiophores, sporangiophore, and vesicles) using identification keys by Davis ${ }^{[12]}$ and Clich ${ }^{[13]}$.

\section{Statistical analysis}

Means for the distribution of concentrations of Aflatoxin were calculated and tested for significance by DMRT at 95 percent confidence level by one-way ANOVA.

\section{Results and Discussion}

The study revealed that twelve (12) fungal species were isolated from different samples of sesame collected from six different Local Government Areas of Benue State. The fungal species identified were: A. flavus, A. fumigatus, $A$. nidulans, A. niger, A. parasiticus, A. tamarrii, A. terreus, A. versicolor, Fusarium oxysporium, Mucor mucedo, Penicillium digitatum, Rhizopus stolonifer. 


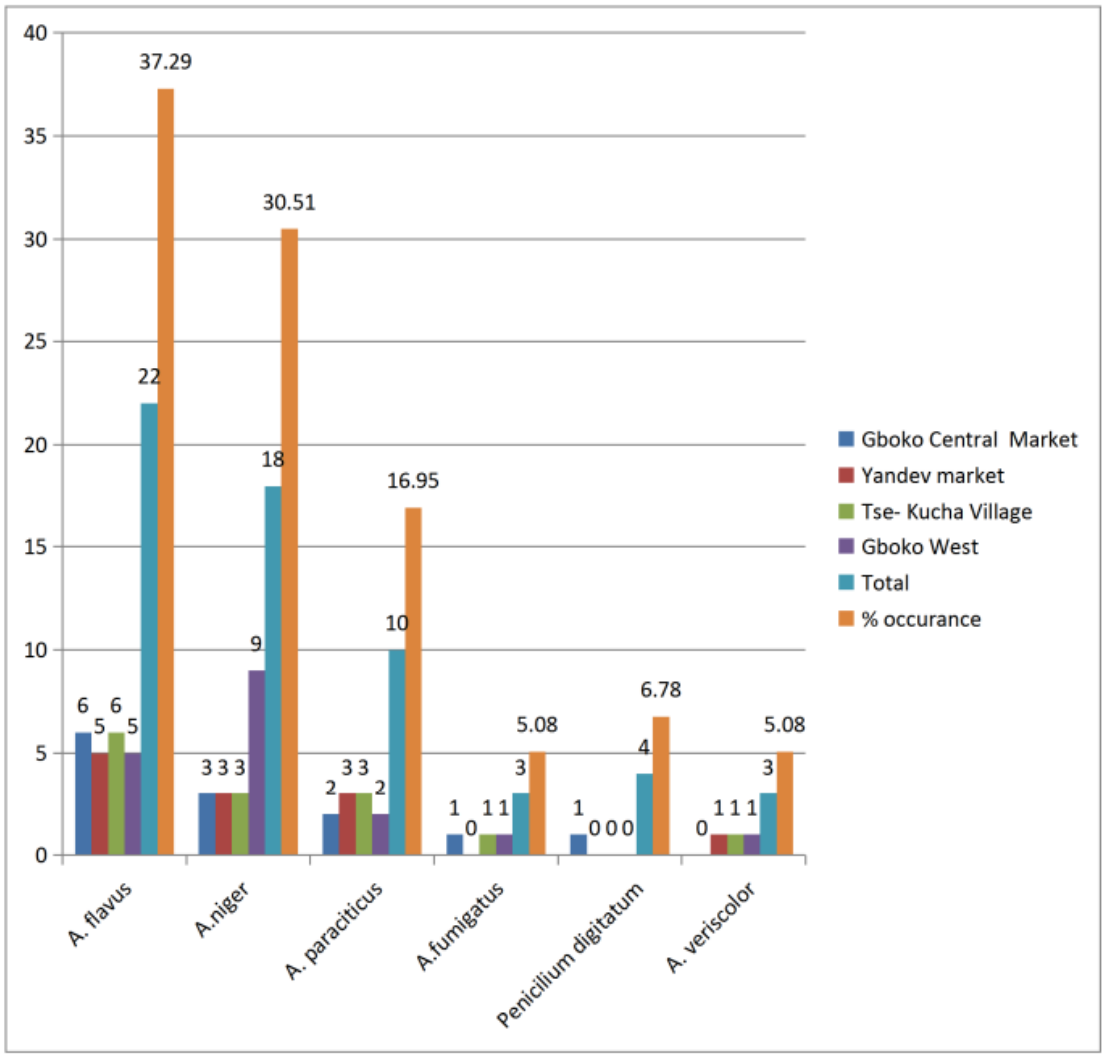

Figure 1. Occurrence (\%) of fungi isolated from samples obtained from Gboko LGA

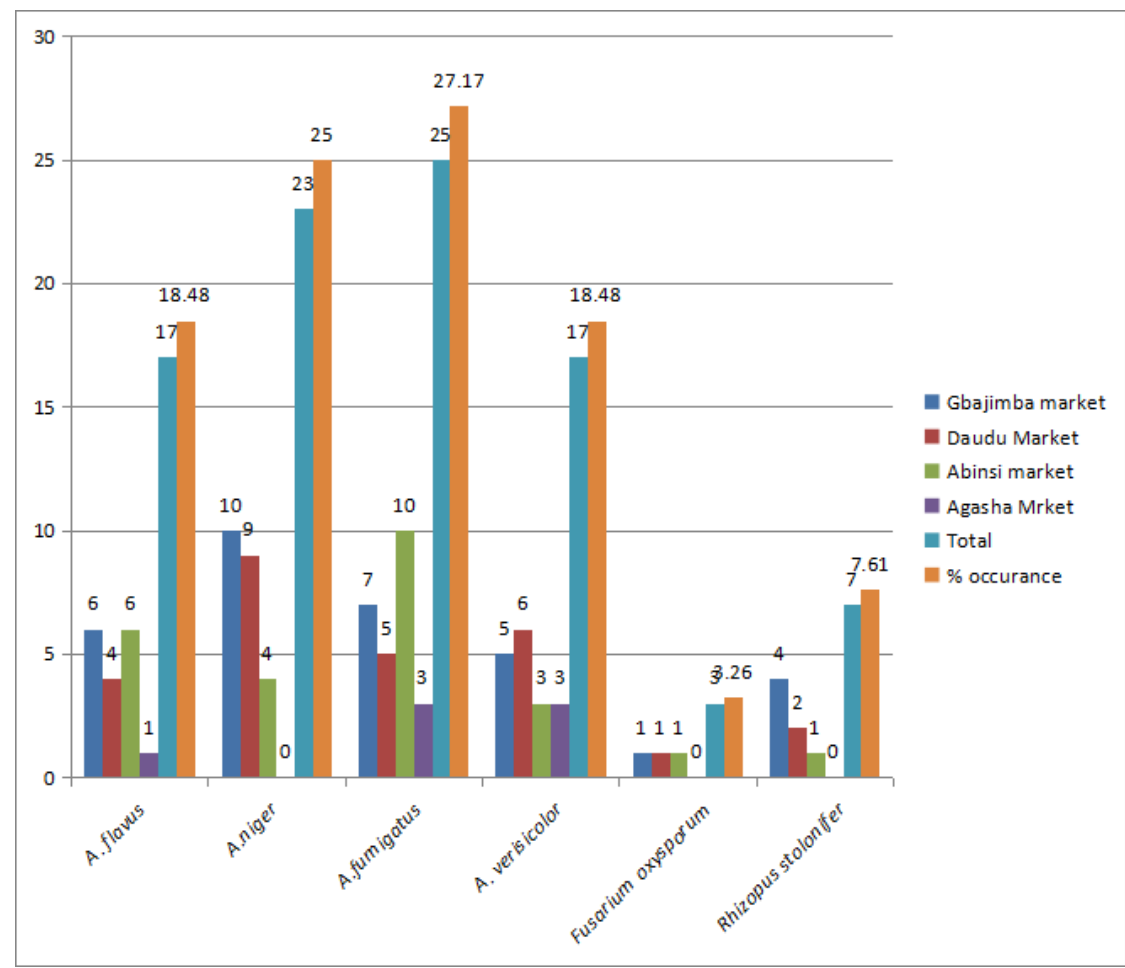

Figure 2. Occurrence (\%) of fungi isolated from samples obtained from Guma 


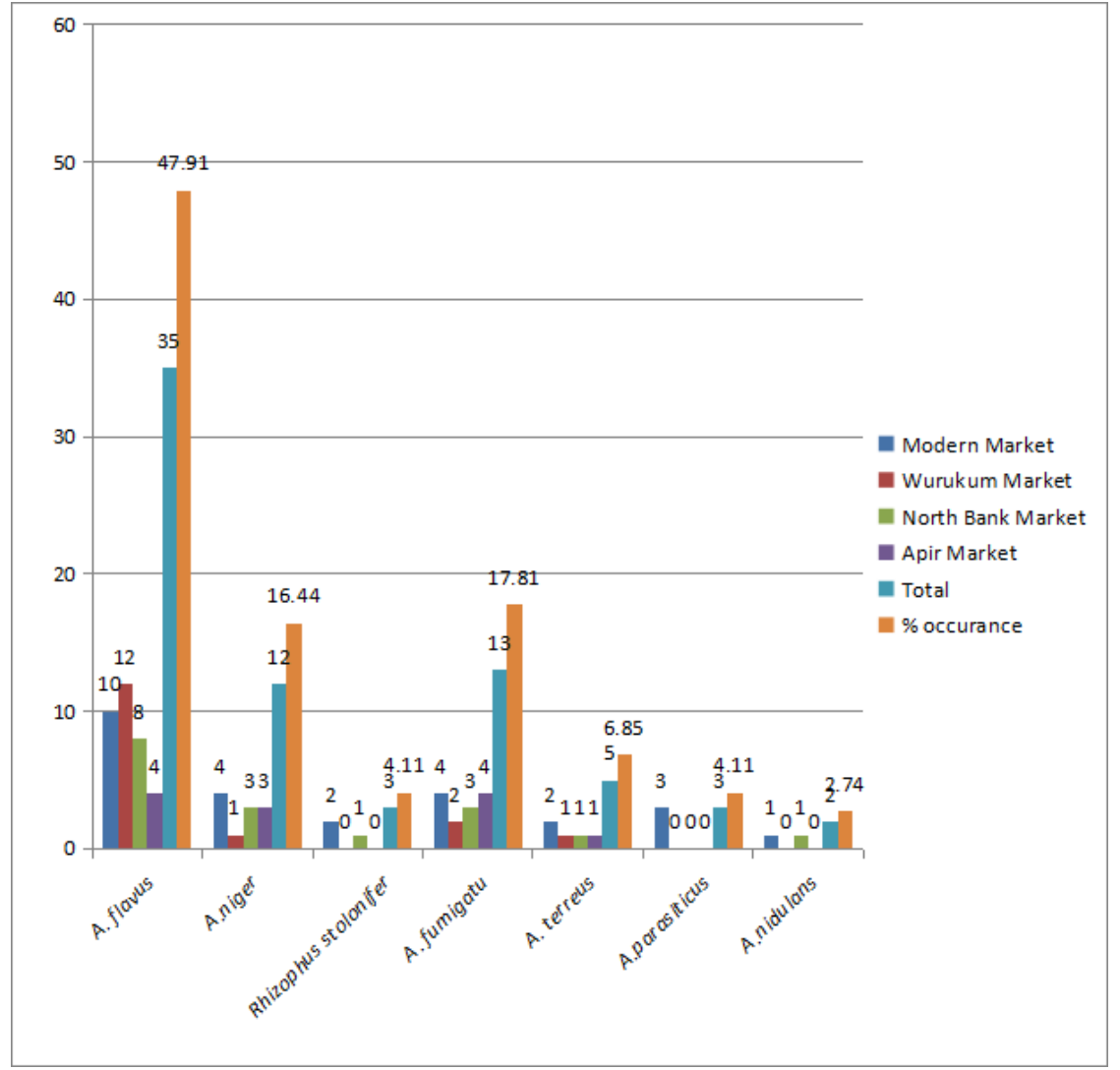

Figure 3. Occurrence (\%) of fungi isolated from samples obtained from Makurdi

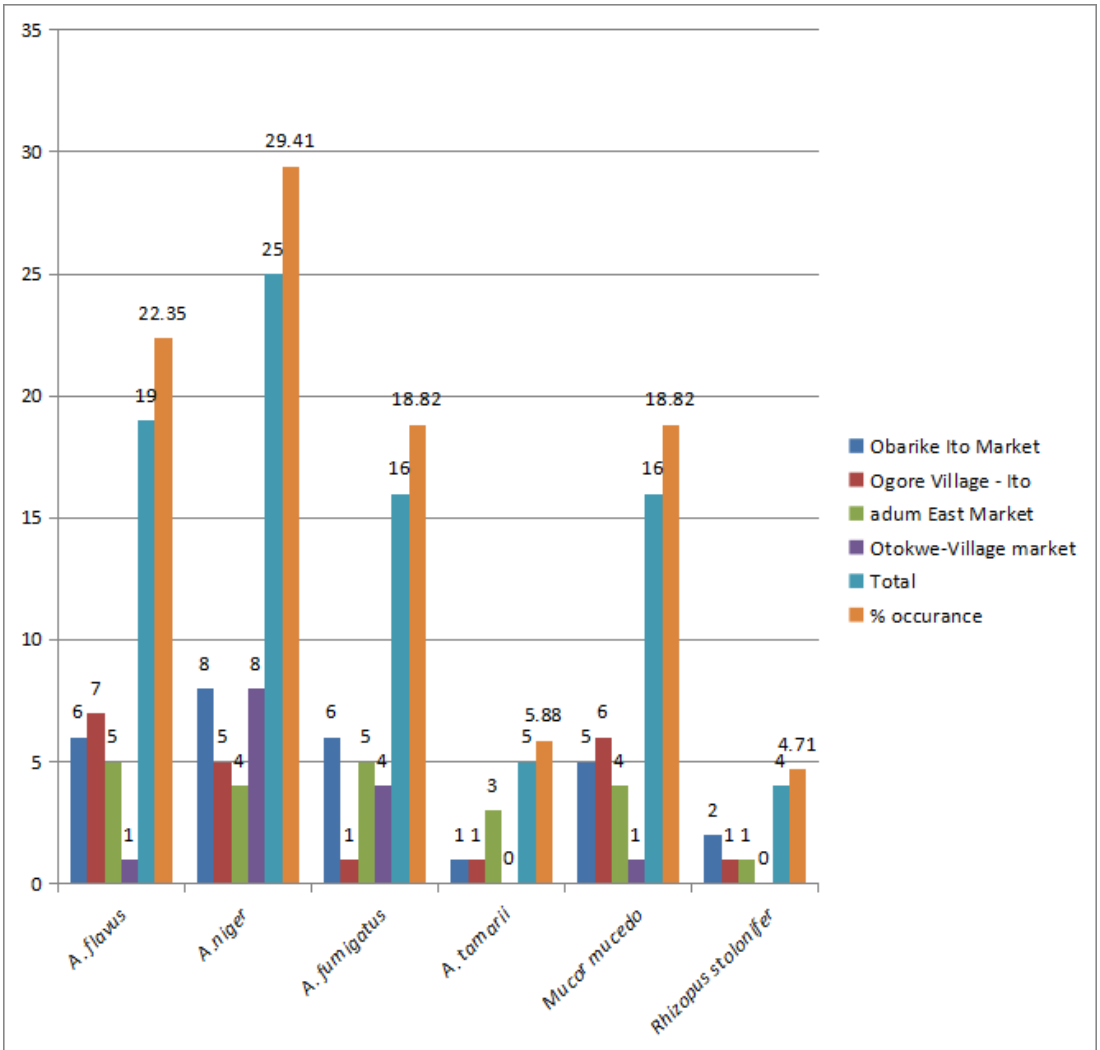

Figure 4. Occurrence ( $\%)$ of fungi isolated from samples obtained from Obi LGA 


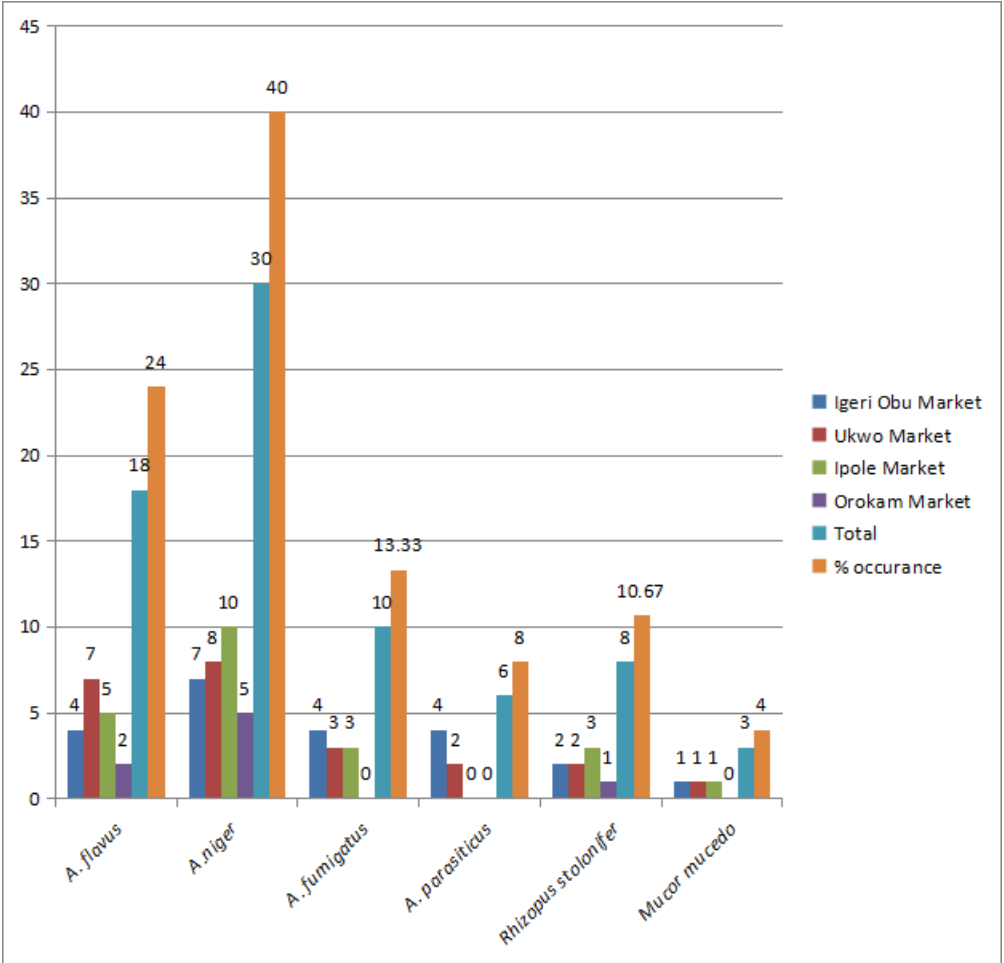

Figure 5. Occurrence (\%) of fungi isolated from samples obtained from Ogbadibo LGA

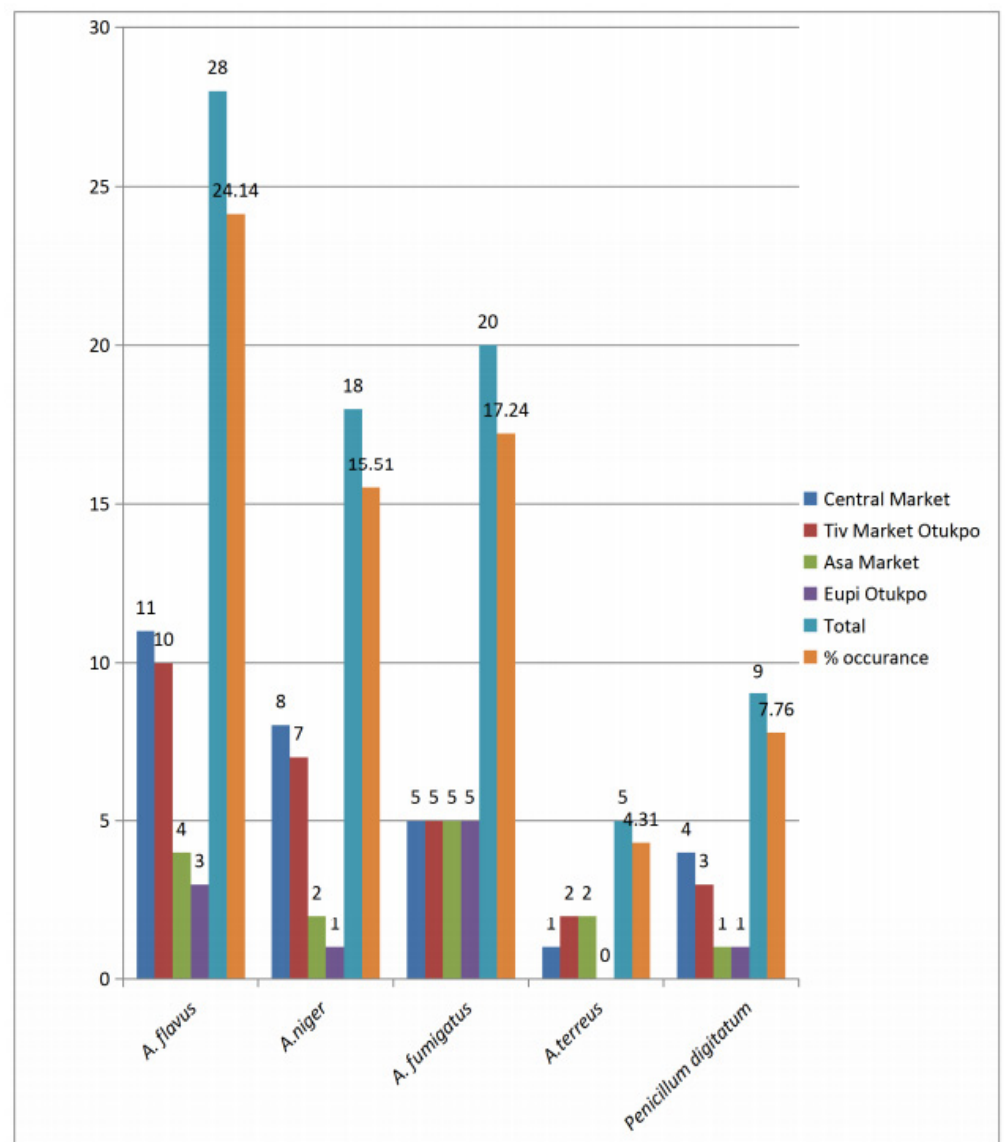

Figure 6. Occurrence (\%) of fungi isolated from samples obtained from Otukpo LGA 
Journal of Botanical Research | Volume 03 | Issue 04 | October 2021

Table 1. Occurrence (\%) of the isolated fungi from six local government areas.

\begin{tabular}{|c|c|c|c|c|c|c|c|c|}
\hline \multirow{2}{*}{ Fungal Isolates } & \multicolumn{6}{|c|}{ Occurrence (\%) of the isolated fungi from } & \multirow{2}{*}{ Total } & \multirow{2}{*}{ Mean No: of Colonies \pm S.E } \\
\hline & Gboko & Guma & Makurdi & Obi & Ogbadib & Otukpo & & \\
\hline A.flavus & $22(36.67)$ & $17(18.45)$ & $35(5.00)$ & $19(22.35)$ & $18(24.00)$ & $28(24.14)$ & $139(27.91$ & $23.2 \pm 2.9^{\mathrm{a}}$ \\
\hline A.fumigatus & $3(5.00)$ & $25(27.17)$ & $13(18.57)$ & $16(18.82)$ & $10(13.33)$ & $20(17.24)$ & $87(17.47)$ & $14.5 \pm 3.2^{\mathrm{a}}$ \\
\hline A.nidulans & $0(0.00)$ & $0 .(0.00)$ & $2(2.86)$ & $0(0.00)$ & $0(0.00)$ & $0(0.00)$ & $2(0.40)$ & $0.33 \pm 0.3^{\mathrm{b}}$ \\
\hline A.niger & $18(30.00)$ & $23(25.00)$ & $12(17.14)$ & $25(29.41)$ & $30(40.00)$ & $18(15.52)$ & $126(25.30)$ & $21.0 \pm 2.6^{\mathrm{a}}$ \\
\hline A.Parasiticus & $10(16.67)$ & $0 .(0.00)$ & $0 .(0.00)$ & $0 .(0.00)$ & $6(8.00)$ & $36(31.03)$ & $52(10.44)$ & $3.2 \pm 1.7^{\mathrm{b}}$ \\
\hline A.tamarii & $0(0.00)$ & $0 .(0.00)$ & $0(0.00)$ & $5(6.01)$ & $0(0.00)$ & $0(0.00)$ & $5(1.00)$ & $0.83 \pm 0.8^{\mathrm{b}}$ \\
\hline A.terreus & $0(0.00)$ & $0(0.00)$ & $5(7.14)$ & $0(0.00)$ & $0(0.00)$ & $5(4.31)$ & $10(2.01)$ & $1.7 \pm 1.11^{\mathrm{b}}$ \\
\hline A.versicolor & $3(3.00)$ & $17(18.48)$ & $0(0.00)$ & $0(0.00)$ & $0(0.00)$ & $0(0.00)$ & $20(4.02)$ & $3.33 \pm 2.8^{\mathrm{b}}$ \\
\hline Fusarium Oxysporum & $0(0.00)$ & $3(3.26)$ & $0(0.00)$ & $0(0.00)$ & $0(0.00)$ & $0(0.00)$ & $3(0.62$ & $0.5 \pm 0.5^{\mathrm{b}}$ \\
\hline Muсоr mисеdo & $0(0.00)$ & $0 .(0.00)$ & $0(0.00)$ & $16(18.82)$ & $3(4.00)$ & $0(0.00)$ & $19(3.82)$ & $3.2 \pm 2.6^{\mathrm{b}}$ \\
\hline Penicillium digitatum & $4(6.67)$ & $0 .(0.00)$ & $0(0.00)$ & $4(4.71)$ & $0(0.00)$ & $9(7.76)$ & $17(3.41)$ & $3.0 \pm 1.5^{\mathrm{b}}$ \\
\hline Rhizopus stolonifer & $0(0.00)$ & $7(7.61)$ & $3(4.29)$ & $0(0.00)$ & $8(10.67)$ & $0(0.00)$ & $18(3.61)$ & $3.0 \pm 1.5^{\mathrm{b}}$ \\
\hline Total & $60(12.05)$ & $92(18.47)$ & $70(14.06)$ & 85.(17.00) & $75(15.06)$ & $116(23.29)$ & 498 & \\
\hline Mean No: of colonies \pm S.E & $5 \pm 2.21^{\mathrm{a}}$ & $7.7 \pm 2.87^{\mathrm{a}}$ & $5.8 \pm 2.9^{\mathrm{a}}$ & $7.1 \pm 2.6^{\mathrm{a}}$ & $6.3 \pm 2.7^{\mathrm{a}}$ & $9.7 \pm 3.7^{\mathrm{a}}$ & & \\
\hline
\end{tabular}

$P$ value

Fungal Isolates: $0.000^{* *}$

\section{Discussion}

Sesame has been reported to be contaminated with different genera of fungi including Alternaria, Aspergillus, Fusarium, penicillium and Cladosporium whereas Aspergillus was the dominant genera ${ }^{[14]}$. Sesame from Otukpo (23.29\%) and Guma (18.47\%) contained more fungi than those obtained from Ogbadibo (15.06\%), Makurdi (14.06\%) and Obi (17.00\%). The variation might be due to the differences in ecological zone and probably of differences in environmental conditions of the area because warm, humidity and climatic conditions favoring fungal growth ${ }^{[14]}$. Another reason for their high incidence might be due to their cosmopolitan nature and they are known to be obligate saprophytes so can survive in the environment with a wide range of temperatures varying from $18-32^{\circ} \mathrm{c}^{[15]}$. Apeh et al. ${ }^{[16]}$ reported that fungi and aflatoxin levels were higher in sesame than millet and sorghum and that Fungi load in sesame seeds increased with latitude.

The Occurrences of different fungal species revealed that Aspergillus species had the highest frequency of occurrence in all sesame obtained from different local government areas.. This result is in agreement with the previous studies that Aspergillus flavus members are common colonizers of all types of millet and sesame during post-harvest storage ${ }^{[17-19]}$, whereas $A$. parasiticus was the dominant one fungi among the Aspergillus genera ${ }^{[14]}$. In another research conducted by Elewaa ${ }^{[20]}$ and Elaigwu et al. ${ }^{[21]}$ showed that sesame has been heavily attacked by many fungi such as $F$. oxysporum, $F$. sesame and Macrophomina phaseolina. Among the Aspergillus species obtained A. flavus and A. niger were the most prevalent and this following the pattern of the findings of Amienyo, et al. ${ }^{[22]}$ that Aspergillus niger showed the highest percentage occurrence of $10.3 \%$ in Sesamum indicum from Faringada market in Nigeria. This might be due to their ability to survive in the range of varying environmental factors (temperature and humidity) as compared to other species isolated. Recently, different species of Alternaria, Aspergillus and Penicillium were isolated from sesame in varying proportions ${ }^{[10]}$.

\section{Conclusions}

The present report is a major investigation into the incidence of fungi in Sesame production in Makurdi Benue state Nigeria. Mycoflora contamination constitutes a major setback to export trade in grains and cereals proceeding from Africa. As a result it poses a challenge to food security in areas that are dependent on these staples. The work necessitates implementation of management and intervention strategies by concerned stakeholders and regulatory bodies. Considering their health and economic implications, there is therefore the need to elucidate the mycotoxin profile of these crops within regions where they are produced and marketed, with a view to generating incidence data which can be used to proffer intervention strategies. In view of the above, there is need for proper orientation and awareness campaign on the impending 
danger of overdependence on sesame in the area sampled.

\section{References}

[1] Kafiriti, E. and Deckers, J. (2001). Sesame (Sesamum indicum L.). In: R.H. Raemaekers, Crop Production in Tropical Africa (pp.797-804). Brussels, Belgium: Directorate General for Inernational Co-operation.

[2] Reddy, S. (2006) Agronomy of field crops. Kalyani Publishers, New Delhi. pp 50-65.

[3] Gururajan, B., Balasubramanian, R., Swaminathan, V. (2008). Recent Strategies on Crop production. Kalyani Publishers, India. Pp; 20-25.

[4] Balasubramanian, T, and Palaniappal, S. (2011). Sesame. In: P. Rathore (Eds.), Techniques and Management of Field Crops Production. Agriculture and Biological sciences, India. pp. 181-200.

[5] Doko, B. and Enwere, S. (2014). Farmer's guide for the production and post-harvest handling of sesame products in Nigeria (Training Mannual). STDF Project 172 co-financed by NEPC and STDF, implemented by NEPC and supervised by ITC. PP.10-11.

[6] Jaya, R. (2007). Daily Trust 24 September. Olam Distributes Sesame Seeds to Farmers in Benue, Nasarawa states. P. 12.

[7] Benue State Agricultural and Rural Development Authority [BNARDA], (2011). Benue state Agricultural and Rural development Authority. Annual report pp. 15-30.

[8] Makun H. A., Apeh D. O., Adeyemi H. R. Y., Nagago T., Okeke J. O., Mustapha A. S. and Oyinloye, B. A. (2014). Determination of Aflatoxins in Sesame, Rice, Millet and Acha from Nigeria using HPLC. Chemical Science Transactions, 3(4), 1516-1524.

[9] Varga, J., Frisvad, J.G, Samson, R.A. (2009). A reappraisal of fungi producing aflatoxins. World Mycotoxin Journal. Volume 2: pp263-267.

[10] Ezekiel, C.N. and Sombie J.I. (2014). Survey of Aflatoxins and Fungi in some Commercial Breakfast Cereals and Pastas retailed in Ogun State, Nigeria. Natural Science 12 (6):27 - 32.

[11] Jha, D. (1995). Laboratory manual on seed pathology. First edition Vikas publishing house New Delhi, India. pp 7-9.

[12] Davise, H. (2002). Important Fungi. A Guide to Identification. 4th Edition, American Society for Microbiology Press, Washington DC, 1-111.
[13] Klich, M. (2002). Identification of Common Aspergillus Species. Utrech. Central Bureeau Voor Schimmel Cultures. The Netherlands, 116.

[14] Bassem, A., Amal S.H, Ahmed N, Soher E.A, Mohamed G.S. (2016). The prevalence of aflatoxin $A$. parasiticus in Egyptian sesame seeds. Journal of Chemical Technology. 9 (11) pp 308-319. USA.

[15] Shehu, K. and Bello, M. T. (2011). Effect of environmental factors in the growth of Aspergillus species associated with stored millet grains in Sokoto. Nigerian Journal of Basic and Applied Sciences, 19 (2): 218-223.

[16] Apeh, D. O., Ochai, D. A., Adejumo, A., Muhammed, H. L., Saidu, H. N., Atehnkeng, J., Adeyemi, R. H., Mailafia, S. C. and Makun, H. A. (2016). Mycological concerns with Sorghum, Millet and Sesame in Northern Nigeria. Journal of Analytical and Bio analytical techniques. 7(5).

[17] Mbah, M. C. and Akueshi C. O. (2009). Aflatoxin in Mould Infested Sesame Seeds. African Journal of Biotechnology, 8(3): 391-394. DOI:10.5897/AJB2009.000-9067.

[18] Makun, H.A., Gbodi, T.A., Tijani, A.S., Abai, A. and Kadir, G.U.( 2007). Toxicological screening of fungi isolated from millet (Pennisetum spp.) during the rainy and dry Harmattan seasons in Niger State, Nigeria. African Journal of Biotechnology.6:34-40.

[19] Diedhiou, P.M., Bandyopadhyay R., Atehnkeng D., Ojionbo P.S. (2011). Aspergillus colonization and aflatoxin contamination of maize and sesame kernels in two agro ecological zones of Senegal. Journal Phytophytology (159):268-275.

[20] Elewaa, S.I., Mostataa M. H., Sahab A.F., Ziedan E. H. (2011) Direct effect of biocontrol agents on wilt and root rot of sesame. Plant protection 44 (5): 493504.

[21] Elaigwu, M., Oluma H.O.A, Ochokwunu, D. I. (2017). In vivo and in vitro activities of some Plant extracts on Macrophomina phaseolina (Tassi) Goidthe causal agent of charcoal rot of sesame in Benue State, Nigeria. International Journal of Science and Research Methodology. 5 (4): 23-39.

[22] Amienyo, C.A., Filibus M.G., Oshatuyi, M. (2015) Effect of fungal deterioration on lipid content of sesame seeds (Sesamum indicum). International Journal of phytopathology. PP 2306-1658. 